\title{
PENGARUH SUHU DAN WAKTU KARBONISASI TERHADAP NILAI KALOR DAN KARAKTERISTIK PADA PEMBUATAN BIOARANG BERBAHAN BAKU PELEPAH AREN (Arenga pinnata)
}

\author{
Erwin Junary, Julham Prasetya Pane, Netti Herlina \\ Departemen Teknik Kimia, Fakultas Teknik, Universitas Sumatera Utara, \\ Jl. Almamater Kampus USU, Medan 20155, Indonesia \\ Email: erwinjunary@yahoo.com
}

\begin{abstract}
Abstrak
Ketersediaan bahan bakar minyak bumi yang berasal dari fosil kian menipis seiring dengan bertambahnya populasi manusia. Tantangan terhadap krisis kekurangan bahan bakar ini tentunya dapat diantisipasi dengan pembuatan bahan bakar yang berasal dari biomassa yang dapat diperbaharui. Penelitian ini bertujuan untuk menciptakan bioarang yang berasal dari pelepah aren (Arenga pinnata) dengan suhu dan waktu karbonisasi yang optimum sehingga diperoleh bioarang dengan nilai kalor yang tinggi. Bioarang adalah arang yang diciptakan dari biomassa. Penelitian penentuan kondisi optimum ini pembuatan bioarang dari pelepah aren (Arenga pinnata) memiliki variabel suhu $300,350,400,450$ dan $500{ }^{\circ} \mathrm{C}$ dan variabel waktu 60,90 dan 120 menit. Pelepah aren yang terlebih dahulu telah dipotong menjadi ukuran yang kecil dan dikeringkan dibawah sinar matahari terlebih dahulu kemudian dimasukkan kedalam furnace untuk dikarbonisasi sesuai dengan variabel yang telah ditentukan, hasil dari furnace kemudian dimasukkan kedalam desikator untuk didinginkan selama 30 menit lalu dilakukan uji kadar air, uji kadar abu, uji kadar bahan volatil, uji kadar karbon terikat dan juga uji nilai kalor. Adapun hasil penelitian terbaik yang diperoleh adalah pada temperature $350{ }^{\circ} \mathrm{C}$ dan waktu 120 menit dengan nilai kalor sebesar $8611,2581 \mathrm{kal} / \mathrm{g}$, kadar air sebesar 5,87 \%, kadar abu sebesar 8,6 \%, kadar bahan volatil sebesar 17,4\% dan kadar karbon terikat sebesar 68,1\%. Berdasarkan nilai kalor yang diperoleh menunjukkan bahwa bioarang pelepah aren (Arenga pinnata) dapat dimanfaatkan sebagai bahan bakar alternatif yang dapat diperbaharui
\end{abstract}

Kata kunci : pelepah aren, karbonisasi, bioarang dan karakteristik

\begin{abstract}
The availability of the petroleum fuels that deprived from fossil is depleted with the increase of human population. The challenge for this fuel shortage crisis can certainly be anticipated with the manufacture of fuels deprived from renewable biomass. The study of this research is to create a biocharcoal deprived from sugar palm (Arenga pinnata) with the optimum carbonization time and temperature in order to obtain a biocharcoal with the highest calorific value. Biocharcoal is a charcoal created from biomass. The study of the determination of the optimum conditions for the manufacture of biocharcoal from sugar palm (Arenga pinnata) has a temperature variable of $300,350,400,450$ and $500{ }^{\circ} \mathrm{C}$ and time variable of 60,90 and 120 minutes. Sugar palm was first cut into a small pieces and dried up under the sun and then put into a furnace to carbonate it according to the predetermined variables. The product from furnace was then put inside a desicator to cool it off for 30 minutes and then analyze it with moisture content test, ash content test, volatile matter content test, carbon content test and calorific value test. The best result was obtained at the temperature of $350{ }^{\circ} \mathrm{C}$ and 120 minutes of carbonization with the calorific value of $8611,2581 \mathrm{cal} / \mathrm{gr}$, moisture content of $\%$, ash content of $\%$, volatile matter content of $\%$ and carbon content of $\%$. Based of the calorific value obtained, the result shows that sugar palm (Arenga pinnata) biocharcoal could be utilize as an renewable alternative source fuels
\end{abstract}

Key words : sugar palm, carbonization, biocharcoal and characteristics

\section{Pendahuluan}

Ketersedian bahan bakar minyak bumi terbatas dan sifatnya tidak terbarukan, sehinga diprediksikan akan terjadi kelangkan bahan bakar minyak dan menimbulkan adanya krisis energi [14]. Selain itu, kenaikan harga bahan bakar minyak menyebabkan kenaikan seluruh harga barang dan jasa. Kenaikan ini memiliki dampak yang signifikan terhadap kebutuhan masyarakat yang mayoritas masih menggunakan bahan bakar minyak dalam pekerjaan mereka [7]. Kebutuhan minyak bumi yang semakin besar merupakan tantangan yang perlu diantisipasi dengan mencari sebuah sumber energi alternatif [3]. Tanaman aren (Arenga pinnata) adalah tanaman perkebunan yang sangat potensial dalam hal 
mengatasi kekurangan pangan dan mudah beradaptasi, pohonnya serbaguna dan telah dikenal menghasilkan bahan - bahan yang dapat dimanfaatkan [4]. Semua bagian fisik dan tumbuhan ini dapat memiliki nilai ekonomis. Pemanfaatan produksi nira sebagai minuman segar atau sebagai bahan baku pengolahan gula telah banyak melibatkan dan memberikan manfaat kepada masyarakat di dalam dan sekitar hutan [11, 12]. Bioarang adalah arang yang diperoleh dengan membakar biomassa kering tanpa udara (pirolisis) sedangkan biomassa adalah bahan organik yang berasal dari jasad hidup. Biomassa sebenarnya dapat digunakan secara langsung sebagai sumber energi panas untuk bahan bakar, tetapi kurang efisien. Nilai bakar biomassa hanya sekitar $3000 \mathrm{kal}$, sedangkan bioarang mampu menghasilkan $5000 \mathrm{kal}$ [6].

\section{Teori}

Pohon aren (Arenga pinnata) seperti pada gambar 1 merupakan pohon yang belum banyak dikenal. Adapun produk utama tanaman aren adalah nira yang biasanya diolah menjadi gula aren dan tuak, kolang-kaling, ijuk, dan tepung. Setiap pohon dapat menghasilkan 15 liter nira per hari dengan rendemen gula $12 \%$. Sementara ijuk yang dihasilkan rata-rata $2 \mathrm{~kg} /$ pohon/tahun, kolang-kaling $100 \mathrm{~kg} /$ pohon/tahun, dan tepung 40 $\mathrm{kg} /$ pohon bila tanaman tidak disadap niranya. Kayu aren dapat diolah menjadi mebel atau kerajinan tangan [16].

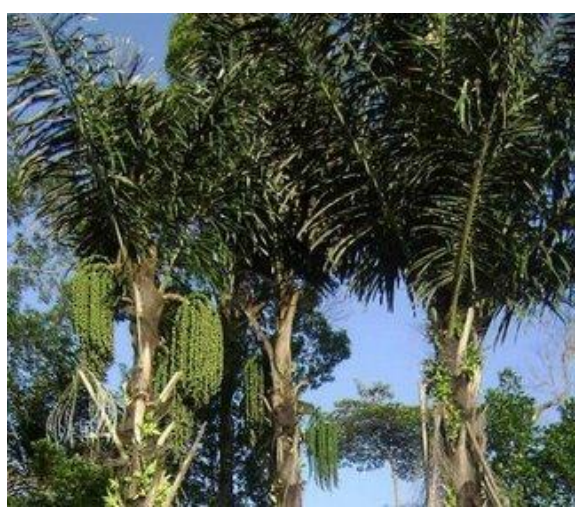

\section{Gambar 1. Pohon Aren}

Arang merupakan bahan padat berpori yang mengandung 85-95 \% karbon dan dihasilkan melalui proses karbonisasi pada suhu tinggi) [18]. Sebagian besar pori - pori arang masih tertutup oleh hidrokarbon, tar dan senyawa organik lain yang komponennya terdiri dari karbon tertambat (fixed carbon), abu, air, nitrogen dan sulfur [6].

Selain sebagai sumber energi untuk menghasilkan panas, arang juga dimanfaatkan sebagai adsorben (penyerap) melalui proses aktivasi yang disebut dengan arang aktif [14].
Tabel 1. Sifat Fisika dan Kimia Arang [5]

\begin{tabular}{|l|l|}
\hline \multicolumn{1}{|c|}{ Variabel } & \multicolumn{1}{c|}{ Ketentuan } \\
\hline Kerapatan & $0,45 \mathrm{~g} / \mathrm{cm}^{3}$ \\
\hline Kerapatan total & $1,38-1,46 \mathrm{~g} / \mathrm{cm}$ \\
\hline Porositas & $70 \%$ \\
\hline Permukaan dalam & $50 \mathrm{~m}$ \\
\hline Kekuatan pemampatan & $26 \mathrm{~N} / \mathrm{mm}^{2}$ \\
\hline Berat bagian terbesar & $80-220 \mathrm{kgm}^{3}$ \\
\hline Kandungan air & $5-8 \%$ \\
\hline Kandungan karbon & $80-90 \%$ \\
\hline Kandungan abu & $1-2 \%$ \\
\hline Nilai kalori & $29-33 \mathrm{MJ} / \mathrm{kg}$ \\
\hline Zat - zat yang mudah menguap & $10-18 \%$ \\
\hline
\end{tabular}

Karbonisasi didefinisikan sebagai suatu proses penghancuran zat organik menjadi arang pada keadaan tanpa udara [13]. Karbonisasi atau pirolisis adalah proses dekomposisi kimia dengan menggunakan pemanasan tanpa adanya oksigen. Proses ini atau disebut juga proses karbonasi atau yaitu proses untuk memperoleh karbon atau arang, disebut juga "High Temperature carbonization" [24]. Karbonisasi biomassa atau yang lebih dikenal dengan pengarangan adalah suatu proses untuk menaikkan nilai kalor biomassa dan dihasilkan pembakaran bersih dengan sedikit asap.

\section{Metodologi Penelitian}

Bahan baku yang digunakan pada penelitian ini ada pelepah aren (Arenga pinnata). Peralatan utama yang digunakan adalah furnace, timbangan, cawan porselen, desikator dan juga moisture analyzer. Adapun variasi dalam percobaan ini adalah sebagai berikut

Tabel 2. Rancangan Variabel Penelitian

\begin{tabular}{|c|c|}
\hline Suhu ( $\left.{ }^{\mathbf{0}} \mathbf{C}\right)$ & Waktu (menit) \\
\hline \multirow{3}{*}{300} & 60 \\
\cline { 2 - 2 } & 90 \\
\cline { 2 - 2 } & 120 \\
\hline \multirow{3}{*}{350} & 60 \\
\cline { 2 - 2 } & 90 \\
\cline { 2 - 2 } & 120 \\
\hline \multirow{3}{*}{400} & 60 \\
\cline { 2 - 2 } & 90 \\
\hline \multirow{3}{*}{450} & 120 \\
\cline { 2 - 2 } & 60 \\
\cline { 2 - 2 } & 90 \\
\hline \multirow{3}{*}{500} & 120 \\
\cline { 2 - 2 } & 60 \\
\cline { 2 - 2 } & 90 \\
\hline
\end{tabular}

Bahan baku awalnya dipotong menjadi ukuran yang lebih kecil lalu dikeringkan dibawah sinar matahari sampai kering. Sampel yang telah kering ini kemudian diambil sebanyak 50 gram , ditaruh pada cawan porselen lalu dimasukkan 
kedalam furnace untuk divariasikan sesuai dengan rancangan variabel penelitian. Hasil dari furnace kemudian didinginkan didalam desikator selama 30 menit lalu dilakukan uji kadar air, uji kadar abu, uji kadar bahan volatil dan uji nilai kalor.

\section{Hasil dan Pembahasan}

Berikut adalah hasil analisis yang menunjukkan karakterisasi dari bioarang pelepah aren

Tabel 3. Hasil Uji Bioarang Pelepah Aren

\begin{tabular}{|c|c|c|c|c|c|c|}
\hline $\begin{array}{l}\text { Suhu } \\
\left({ }^{\circ} \mathrm{C}\right)\end{array}$ & $\begin{array}{l}\text { Waktu } \\
\text { (menit) }\end{array}$ & $\begin{array}{l}\text { Nilai } \\
\text { Kalor } \\
\text { (kal/g) }\end{array}$ & $\begin{array}{c}\text { Kadar } \\
\text { Air } \\
(\%)\end{array}$ & $\begin{array}{c}\text { Kadar } \\
\text { Abu } \\
(\%)\end{array}$ & $\begin{array}{c}\text { Kadar } \\
\text { Zat } \\
\text { Mudah } \\
\text { Menguap } \\
(\%)\end{array}$ & $\begin{array}{c}\text { Kadar } \\
\text { Karbon } \\
\text { Terikat } \\
(\%)\end{array}$ \\
\hline \multirow{3}{*}{300} & 60 & 3163,3193 & 6,80 & 5,6 & 31,4 & 56,2 \\
\hline & 90 & 4393,4990 & 6,32 & 6,8 & 28,4 & 58,5 \\
\hline & 120 & 6150,8986 & 6,21 & 7,0 & 23,4 & 63,4 \\
\hline \multirow{3}{*}{350} & 60 & 5096,4588 & 6,11 & 7,2 & 20,6 & 66,1 \\
\hline & 90 & 7029,5984 & 6,03 & 8,2 & 18,4 & 67,4 \\
\hline & 120 & 8611,2581 & 5,87 & 8,6 & 17,4 & 68,1 \\
\hline \multirow{3}{*}{400} & 60 & 5447,9388 & 5,73 & 11,4 & 17,0 & 65,9 \\
\hline & 90 & 6150,8986 & 5,65 & 12,0 & 16,2 & 66,1 \\
\hline & 120 & 6502,3785 & 5,53 & 12,2 & 15,4 & 66,9 \\
\hline \multirow{3}{*}{450} & 60 & 4569,2390 & 5,51 & 12,4 & 14,8 & 67,3 \\
\hline & 90 & 4217,7590 & 5,45 & 13,6 & 14,6 & 66,3 \\
\hline & 120 & 4042,0191 & 5,31 & 14,8 & 14,2 & 65,7 \\
\hline \multirow{3}{*}{500} & 60 & 4569,2390 & 5,27 & 15,2 & 14,0 & 65,5 \\
\hline & 90 & 4042,0191 & 5,01 & 17,2 & 13,0 & 64,8 \\
\hline & 120 & 3690,5391 & 4,89 & 19,8 & 11,8 & 63,5 \\
\hline
\end{tabular}

Pengaruh Suhu dan Waktu Karbonisasi terhadap Kadar Air Bioarang Pelepah Aren

Kadar air adalah jumlah air yang terkandung didalam suatu material [17]. Kadar air berbanding terbalik dengan nilai kalor sehingga penurunan kadar air akan menyebabkan kenaikan nilai kalor [2].

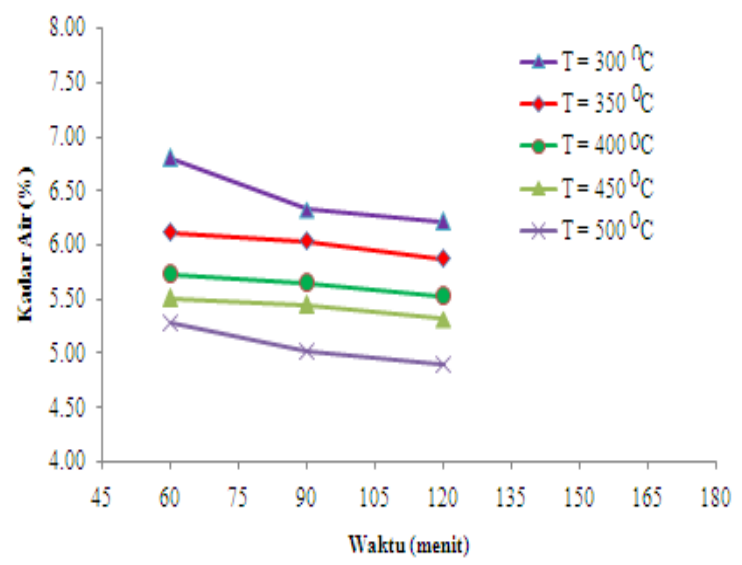

Gambar 2. Pengaruh Suhu dan Waktu Karbonisasi terhadap Kadar Air pada Bioarang Pelepah Aren

Gambar 2 menunjukkan kecenderungan grafik menurun seiring dengan bertambahnya suhu dan waktu karbonisasi, Hal ini sesuai dengan teori dimana semakin lama waktu karbonisasi maka kadar air akan semakin berkurang [21].
Semakin lama waktu karbonisasi maka pori - pori dari arang akan semakin terbuka mengakibatkan lepasnya kadar air yang terdapat didalam bahan [8]

\section{Pengaruh Suhu dan Waktu Karbonisasi terhadap Kadar Abu Bioarang Pelepah Aren}

Abu adalah zat - zat anorganik yang berupa logam ataupun mineral yang merupakan sisa hasil pembakaran [22]. Semakin rendah kadar abu maka kualitas briket yang dihasilkan semakin bagus [10].

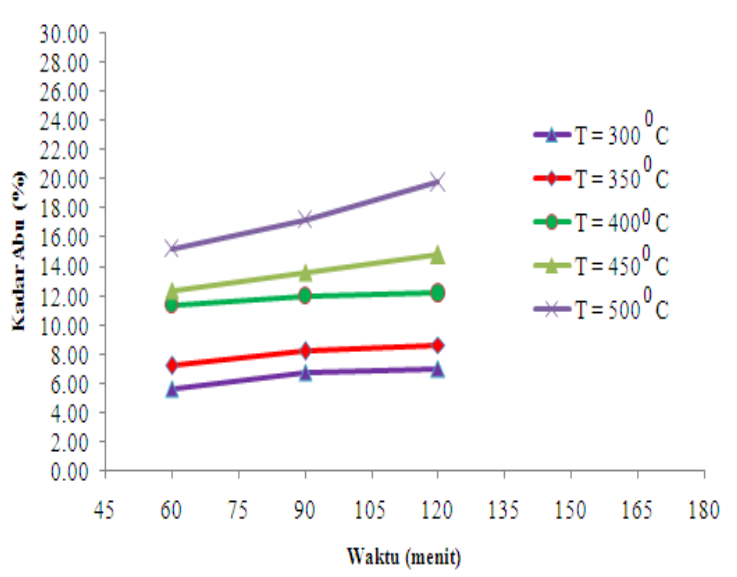

Gambar 3. Pengaruh Suhu dan Waktu Karbonisasi terhadap Kadar Abu pada Bioarang Pelepah Aren

Gambar 3 menunjukkan kecenderungan grafik meningkat seiring dengan bertambahnya suhu dan waktu karbonisasi. Hal ini sesuai dengan teori dimana semakin lama waktu karbonisasi maka kadar abu akan semakin meningkat karena karbon akan habis terbakar dan menyisakan abu yang merupakan hasil sisa pembakaran [24]. Keberadaan abu yang berlebihan dapat menyebabkan terjadinya penyumbatan pori - pori pada arang sehingga luas permukaan arang menjadi berkurang [19].

\section{Pengaruh Suhu dan Waktu Karbonisasi terhadap Kadar Zat Mudah Menguap Bioarang Pelepah Aren}

Kadar zat mudah menguap atau volatile matter itu berhubungan dengan kecepatan pembakaran. Volatile matter itu sendiri merupakan zat - zat organik yang tersimpan dalam suatu bahan dan dengan pemanasan pada suhu yang tinggi maka zat volatile ini dapat dihilangkan. Zat volatil yang terlalu tinggi akan membuat kadar karbon dalam arang hilang sehingga hal ini juga akan menurunkan kualitas dari arang itu sendiri [23]. 


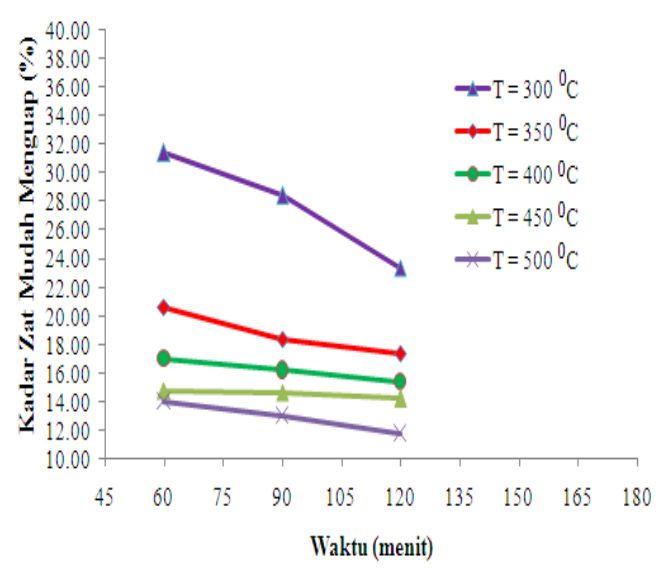

Gambar 4. Pengaruh Suhu dan Waktu Karbonisasi terhadap Kadar Zat Mudah Menguap pada Bioarang Pelepah Aren

Gambar 4 menunjukkan kecenderungan grafik menurun seiring dengan bertambahnya suhu dan waktu karbonisasi. Hal ini sesuai dengan teori dimana semakin lama waktu karbonisasi maka kadar zat mudah menguap akan semakin berkurang [21]. Kadar zat mudah menguap berhubungan terbalik dengan pembakaran dimana bila kadar zat mudah menguap semakin besar maka lama pembakaran akan semakin kecil namun waktu penyalaan api akan semakin singkat [23].

Pengaruh Suhu dan Waktu Karbonisasi terhadap Kadar Karbon Terikat Bioarang Pelepah Aren

Kadar karbon merupakan jumlah karbon murni yang terkandung di dalam arang. Suhu yang semakin tinggi pada proses karbonisasi sangat berpengaruh pada kualitas dari arang, termasuk kadar karbon [21]

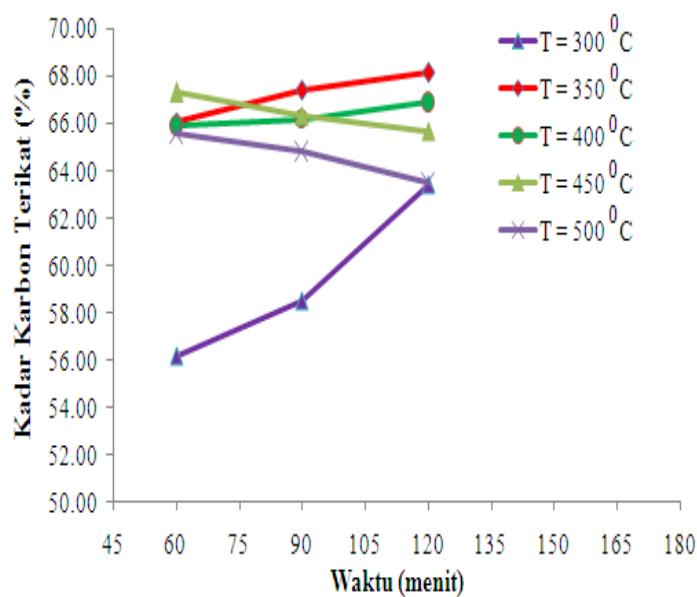

Gambar 5. Pengaruh Suhu dan Waktu Karbonisasi terhadap Kadar Karbon Terikat pada Bioarang Pelepah Aren
Gambar 5 Menunjukkan kenaikan kadar karbon seiring dengan bertambahnya suhu dan waktu karbonisasi namun terjadi penyimpangan pada suhu 450 dan $500{ }^{\circ} \mathrm{C}$ dimana grafik malah menunjukkan penurunan. Hal ini dikarenakan pada suhu yang terlalu tinggi, proses karbonisasi cenderung merusak dinding - dinding pori karbon sehingga karbon yang terbentuk semakin sedikit [9].

\section{Pengaruh Suhu dan Waktu Karbonisasi terhadap Nilai Kalor Terikat Bioarang Pelepah Aren}

Nilai kalor adalah nilai yang menyatakan jumlah panas yang terkandung pada suatu bahan bakar. Nilai kalor merupakan kualitas utama untuk sebuah bahan bakar [18].

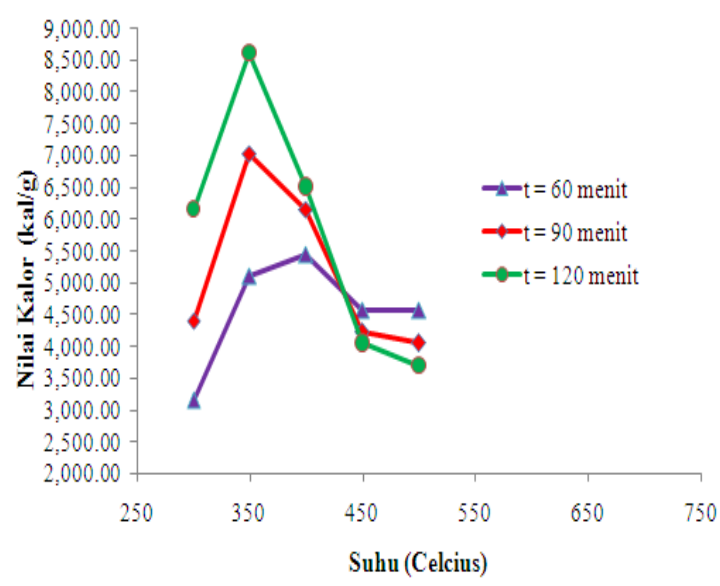

Gambar 6. Pengaruh Suhu Karbonisasi terhadap Nilai Kalor pada Bioarang Pelepah Aren

Gambar 6 Menunjukkan hubungan suhu karbonisasi dengan nilai kalor dimana dilihat pada grafik bahwa titik optimum berada pada suhu 350 ${ }^{0} \mathrm{C}$ dengan waktu 120 menit. Hal ini terjadi karena proses karbonisasi cenderung merusak dinding dinding pori karbon sehingga karbon yang terbentuk semakin sedikit [9]. Jika karbon rusak maka nilai kalor juga akan semakin menurun karena kadar karbon berbanding lurus dengan nilai kalor yang dihasilkan [18]. Kualitas dari bioarang yang paling utama ditentukan melalui nilai kalornya yang dihitung dengan menggunakan alat kalorimeter bom karena nilai kalor lah yang menjadi acuan apakah bioarang tersebut layak digunakan sebagai bahan bakar pengganti minyak atau tidak. Jika nilai kalor terlalu kecil maka nilai ekonomis dari bioarang tersebut juga akan kecil sehingga tidak menguntungkan apabila dipakai sebagai pengganti bahan bakar minyak 


\section{Pengaruh Kadar Air Terhadap Kadar Karbon Terikat Bioarang Pelepah Aren}

Kadar air adalah jumlah air yang terkandung didalam suatu material [17]. Kadar air berbanding terbalik dengan nilai kalor sehingga penurunan kadar air akan menyebabkan kenaikan nilai kalor [2].

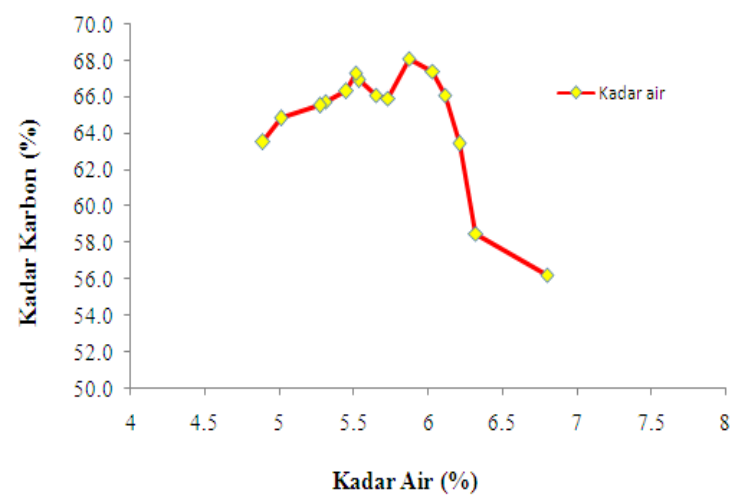

Gambar 7. Pengaruh Kadar Air terhadap Kadar Karbon Terikat pada Bioarang Pelepah Aren

Pada gambar 7 dapat dilihat bahwa pada semakin rendah kadar air maka kadar karbon yang dihasilkan akan semakin tinggi. Hal ini sesuai dengan teori dimana Kadar karbon merupakan pengurangan jumlah terhadap kadar air, kadar abu dan kadar volatil yang terkandung didalam arang [1].

\section{Pengaruh Kadar Abu Terhadap Kadar Karbon Terikat Bioarang Pelepah Aren}

Abu adalah zat - zat anorganik yang berupa logam ataupun mineral yang merupakan sisa hasil pembakaran [22]. Semakin rendah kadar abu maka kualitas briket yang dihasilkan semakin bagus [10].

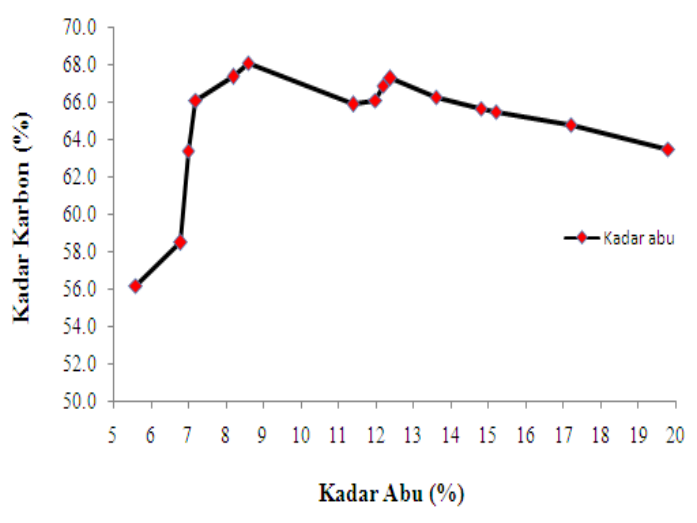

Gambar 8. Pengaruh Kadar Abu terhadap Kadar Karbon Terikat pada Bioarang Pelepah Aren
Pada gambar 8 dapat dilihat bahwa pada semakin rendah kadar abu maka kadar karbon yang dihasilkan akan semakin rendah dan semakin tinggi kadar abu maka kecenderungan kadar karbon untuk meningkat. Hal ini tidak sesuai dengan teori dimana Kadar karbon akan menurun jika terjadi penambahan kadar abu karena kadar karbon merupakan pengurangan jumlah terhadap kadar air, kadar abu dan kadar volatil yang terkandung didalam arang [1].

Penyimpangan ini terjadi karena pada saat karbonisasi dengan suhu dan waktu yang lebih tinggi, terjadi penurunan kadar air dan kadar volatil yang menyebabkan penambahan daripada kadar karbon itu sendiri sehingga jika diliat secara terpisah melalu hubungan antara kadar abu dan kadar karbon, maka hal ini terlihat seperti penyimpangan dimana seharusnya semakin kekanan atau semakin besar kadar abu, kadar karbon seharusnya menurun

Pengaruh Kadar Bahan Volatil Terhadap Kadar Karbon Terikat Bioarang Pelepah Aren

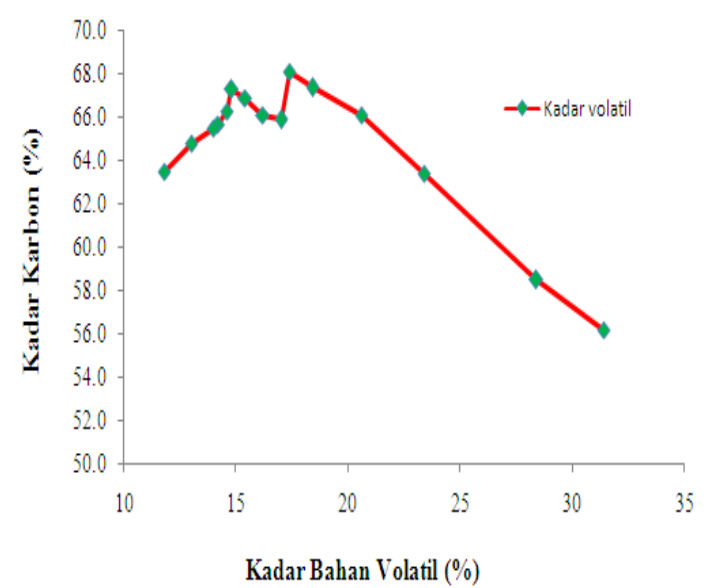

Gambar 9. Pengaruh Kadar Bahan Volatil terhadap Kadar Karbon Terikat pada Bioarang Pelepah Aren

Pada gambar 9 dapat dilihat bahwa pada semakin rendah kadar bahan volatil maka kadar karbon akan semakin tinggi dan semakin tinggi kadar bahan volatil maka kadar karbon akan semakin rendah, hal ini memunculkan kecenderungan penuruan pada grafik yang didapat. Hal ini sesuai dengan teori dimana kadar karbon merupakan pengurangan jumlah terhadap kadar air, kadar abu dan kadar volatil yang terkandung didalam arang [1].

Jadi semakin rendah kadar bahan volatil maka kadar karbon akan semakin bertambah dan juga sebaliknya. 


\section{Pengaruh Kadar Karbon Terikat Terhadap Nilai Kalor Bioarang Pelepah Aren}

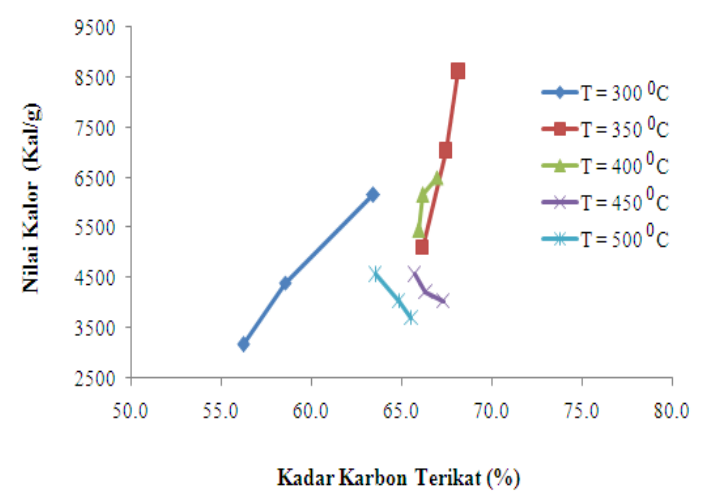

\section{Gambar 10. Pengaruh Kadar Karbon Terikat terhadap Nilai Kalor pada Bioarang Pelepah Aren}

Pada gambar 10 dapat dilihat bahwa hubungan kadar karbon terhadap nilai kalor berbanding lurus dimana bila kadar karbon mengalami kenaikan maka nilai kadar juga akan semakin tinggi dan juga sebaliknya. Menurut teori Jika karbon rusak maka nilai kalor juga akan semakin menurun karena kadar karbon berbanding lurus dengan nilai kalor yang dihasilkan [18].

Pada suhu 450 dan $500{ }^{0} \mathrm{C}$ terdapat penyimpangan dimana nilai karbon justru mengalami penurunan seiring dengan bertambahnya suhu dan waktu karbonisasi, hal ini disebabkan karena pada suhu tinggi dan waktu pemanasan yang lama proses karbonisasi cenderung merusak dinding - dinding pori karbon sehingga karbon yang terbentuk semakin sedikit [9].

\section{Kesimpulan}

Kesimpulan yang didapat dari hasil penelitian ini adalah:

1. Semakin lama waktu karbonisasi dan semakin tinggi suhu maka kadar air dan kadar zat volatil akan semakin berkurang, namun hal ini akan berlaku sebaliknya untuk kadar abu.

2. Nilai kalor berbanding lurus dengan kadar karbon terikat, semakin besar kadar karbon terikat maka nilai kalor akan semakin tinggi dan sebaliknya

3. Kadar karbon dipengaruhi oleh kadar air, kadar abu dan kadar zat mudah menguap , apabila ketiganya terdapat dalam jumlah yang kecil maka kadar karbon akan semakin besar dan sebaliknya
4. Berdasarkan analisa yang telah dilakukan maka kondisi optimum pada pembuatan bioarang pelepah aren adalah pada suhu 350 ${ }^{0} \mathrm{C}$ dengan waktu 120 menit dimana didapat kadar air sebesar 5,87\%, kadar abu sebesar $8,6 \%$, kadar zat volatil sebesar $17,4 \%$, kadar karbon terikat 68,1 \% dan nilai kalor sebesar $8611,2581 \mathrm{kal} / \mathrm{g}$

\section{Daftar Pustaka}

[1] ASTM D 5142-02, Standards Test Methods for Proximate Analysis of The Analysis Sample of Coal and Coke by Instrumental Procedures, 2010.

[2] Daniel Romatua, Kajian Eksperimental Pengaruh Pengurangan Kadar Air terhadap Nilai Kalor pada Bahan Bakar Padat, Skripsi, Departemen Teknik Mesin, Fakultas Teknik, Universitas Sumatera Utara, 2007.

[3] Darmawan, Ferry Indra dan I Wayan Susila, Proses Produksi Biodiesel dari Minyak Jelantah dengan Metode Pencucian Dry Wash System, Jurnal Teknik Mesin, Vol 2, No. 1, 2013.

[4] Effendy, Dedi Soleh, Prospek Pengembangan Tanaman Aren (Arenga pinnata merr) Mendukung Kebutuhan Bioetanol Indonesia, Perspektif, ISSN : 1412 - 8004, Vol 9, No. 1,: 36 - 46, 2010.

[5] Ensiklopedia Nasional Indonesia, Sifat Fisika dan Kimia Arang, Jil.2, Departemen Pendidikan Nasional, Jakarta, 1995.

[6] Fachry, A. Rasyidi., Sari, Tuti Indah., Dipura, Arco Yudha dan Jasril Najamudin, Teknik Pembuatan Briket Campuran Eceng Gondok dan Batubara sebagai Bahan Bakar Alternatif bagi Masyarakat Pedesaan, ISBN:978-979-95620-6-7, Jurusan Teknik Kimia, Fakultas Teknik, Universitas Sriwijaya, 2010.

[7] Hanandito, Lafas dan Sulthon Willy, Pembuatan Briket Arang Tempurung Kelapa dari Sisa Bahan Bakar Pengasapan Ikan Kelurahan Bandarharjo Semarang, Jurusan Teknik Kimia, Fakultas Teknik, Universitas Diponegoro, 2011.

[8] Hartanto, Singgih dan Ratnawati, Pembuatan Karbon aktif dari Tempurung Kelapa Sawit dengan Metode Aktivasi Kimia, Jurnal Sains Materi Indonesia, ISSN : 1411-1098, Vol. 12, No. 1, 2010.

[9] Hartoyo dan Nurhayati, Pengaruh Berat Jenis Kayu Daun Lebar terhadap Sifat Arang, Lembaga Penelitian Hasil Hutan Bogor, 1976.

[10] Hendra dan Darmawan, Pengaruh Bahan Baku, Jenis Perekat dan Tekanan Kempa 
Terhadap Kualitas Briket Arang, Puslitbang Hasil Hutan, Bogor, 2000.

[11] Iswanto, Apri Heri, Aren (Arenga pinnata), Karya Tulis Ilmiah, Departemen Kehutanan, Fakultas Pertanian, Universitas Sumatera Utara, 2009.

[12] Lempang, Mody, Pohon Aren dan Manfaat Produksinya, Info Teknis EBONI, Vol. 9, No. 1,: 37-54, 2012.

[13] Menendez, R. dan Alvarez, R, Coal Carbonization : Current and Future Applications, Instituto Nacional Del Carbon y sus Derivados, 2003.

[14] Murniati, Rini, Karakterisasi Biodiesel dari Minyak Jelantah Hasil Fisisorpsi Zeolit Alam Teraktivasi, Skripsi, Jurusan Fisika, Fakultas Ilmu Matematika dan Ilmu Pengetahuan Alam, Universitas Andalas, 2011.

[15] Pari, Gustan, Mahfudin dan Jajuli, Teknologi Pembuatan Arang, Briket Arang dan Arang Aktif serta Pemanfaatannya, Gelar Teknologi Tepat Guna oleh Badan Penelitian dan Pengembangan Kehutanan, 2012.

[16] Pribadi, Ning, Pohon Aren, Sumber Energi Alternatif, Warta Penelitian dan Pengembangan Pertanian, ISSN 02164427, Vol. 31 No. 2, 2009.

[17] Robert Govett, Terry Mace dan Scott Bowe, A Practical Guide for the Determination of Moisture Content of Woody Biomass, University of Wisconsin, 2010.

[18] Sari, Optimasi Nilai Kalor Pembakaran Biobriket Campuran Batubara dengan Arang Tempurung Kelapa, Skripsi, Fakultas Matematika dan Ilmu Pengetahuan Alam, Universitas Sebelas Maret, 2011.

[19] Scroder Eliabeth, Experiment on the Generation of activated carbon from Biomass, Institute for Nuclear and energy Technologies Forschungs Karlsruhe, Germany, 2006.

[20] Sembiring, Meilita Tryana dan Tuti Sarma Sinaga, Arang Aktif (Pengenalan dan Proses Pembuatannya), Karya Ilmiah, Departemen Teknik Industri, Fakultas Teknik. Universitas Sumatera Utara, 2003.

[21] Siahaan, Satriyani, Melvha Hutapea dan Rosdanelli Hasibuan, Penentuan Kondisi Optimum Suhu dan Waktu Karbonisasi pada Pembuatan Arang dari Sekam Padi, Jurnal Teknik Kimia USU, 2(1), 2013.
[22] Vanessa, Penentuan Kadar Air dan Kadar Abu dari Gliserin yang Diproduksi PT. Sinar OleoChemical International Medan, Skripsi, Departemen Kimia, Matematika dan Ilmu Pengetahuan Alam, Universitas Sumatera Utara, 2008.

[23] Wahyu Kusuma A.,Sarwono dan Ronny Dwi Noriyati, Kajian Studi Eksperimental Terhadap Karakteristik Pembakaran Briket Limbah Ampas Kopi Instan dan Kulit Kopi (Studi kasus di Pusat Penelitian Kopi dan Kakao Indonesia), Jurnal Teknik Pomits, Teknik Fisika, Fakultas Teknologi Industri, Insitut Teknologi Sepuluh November, 2013.

[24] Yudanto, Angga dan Kartika Kusumaningrum, Pembuatan Briket Bioarang dari Arang Serbuk Gergaji Kayu Jati, Skripsi, Jurusan Teknik Kimia, Fakultas Teknik, Universitas Diponegoro, 2009. 